\title{
Judeans Outside the Main Archives
}

The great majority of documents pertaining to Judeans in Babylonia belong to the text groups discussed in Chapters $2-5$. The texts predominantly originate from the land-for-service sector of Babylonian agriculture, where the majority of foreign deportees apparently worked. A modest number of miscellaneous texts diversify this picture somewhat, showing that some Judeans lived in the sphere of Babylonian temples while others worked as royal officials outside the land-for-service sector. However, these documents emphasise the connection between Judeans and Babylonian institutions, especially the royal administration. Even texts from private archives betray the close ties between Judeans and royal lands. As the texts discussed in this chapter originate from multiple archives and geographical locations, they will be discussed in thematic categories. $^{1112}$

\subsection{Officials}

The previous chapters have shown that although the majority of Judeans worked as farmers in the land-for-service sector, some of them served the local or state administration as officials. A Judean sēpiru and a group of Judean courtiers were stationed in Babylon, ${ }^{1113}$ and a number of Judeans worked as minor officials in the land-for-service sector in the environs of Yāhūdu and Nippur. ${ }^{1114}$ An additional five documents enrich this picture.

1112 These texts and their archival connections are briefly discussed and catalogued in Zadok 2002, 2004, 2014a; Waerzeggers 2014b. Almost all texts are transliterated at CTIJ, and the photos of some tablets are available at CDLI (http://cdli.ucla.edu/). In addition to the texts discussed below, Zadok has identified Judeans in a number of unpublished texts which I could not access when preparing this study. These include tablet no. 192 at the Institute for Antiquity and Christianity, Claremont Graduate University (Zadok 2002, 27-28 no. 8); BM 59765 (Pinches 1892b, 15; cf. Zadok 2002, 35 no. 55 with an erroneous BM number); and Pinches 1910, 63 no. 3:19 (the museum number given by Pinches is mistaken; see Zadok 2002, 45 no. 156). A prosopographical database of Judeans outside the Yāhūdu corpus and the Murašû archive is available online at https://doi.org/10.5281/ zenodo.3354074.

1113 Section 2.4.

1114 Sections 4.4 and 5.4 . 
The most notable Judean official known to us was a certain Gadal-Yāma/ Banna-Ea, who is attested in Babylon in 24-VI-36 Dar (486 в СЕ, BM $74554=$ Stolper 1989). ${ }^{1115} \mathrm{Hu}-\mathrm{ta}-\mathrm{x}-\mathrm{x}^{-2}{ }^{2} /$ Pagakanna (the governor of Babylon and Acrossthe-River), Liblut (sēpiru bēl țēmi), and Gadal-Yāma/Banna-Ea (sēpiru bēl țēmi) authorised Șihā/Ahulap, the chief of the prison of a brickworks, ${ }^{1116}$ to collect a tax payment of 14 kurru of barley. The governor of Babylon and Across-theRiver was in charge of an important province of the Persian Empire, ${ }^{1117}$ and Libluṭ and Gadal-Yāma apparently belonged to the administrative personnel at his disposal. As was discussed in Section 5.3.2, the title sêpiru could be held by ordinary scribes competent in Aramaic but also by officials of a higher rank. The latter seems to be the case here. The title bèl têmi is rare in Babylonian documents, ${ }^{1118}$ but the term $b^{\varsigma} l t^{\varsigma} m$ is also attested in contemporary Aramaic. ${ }^{1119}$ There seems to have been a close connection between the officials called bèl têmi and the provincial administration of the Persian Empire. ${ }^{1120}$ The most notable example is a document from Egypt mentioning a certain Anani (' $n n y)$, who issued an administrative order on behalf of the governor of Egypt. ${ }^{1121}$ In light of this evidence, Gadal-Yāma is a unique example of a Judean working in the provincial administration in Babylonia. Moreover, the document records a rare occasion of a Judean being in an authoritative position in relation to a member of the Babylonian urban elite. The taxpayer Iddin-Bēl/Iqī̌sa-Marduk/ Šangû-Šamaš belonged to a Sipparean prebendary family. ${ }^{1122}$

Another document from Babylon (BM 26553 = Bloch 2018 no. 79, ${ }^{1123} 3$-X-14 Dar, 507 BCE) records a similar case. Nabû-zēr-ušebši/Nabû-ēṭir-napšāti, a member of the important Borsippean prebendary family of Ilia, ${ }^{1124}$ and a certain Ṭābia/Nabû-êtị/Rēš-ummāni made a tax payment of 15 kurru of barley to

\footnotetext{
1115 On this document, see most recently Bloch 2018, 277-281.

1116 l'

1117 Stolper 1989, 288-298; Pearce 2015, 17-18.

1118 Stolper 1989, 299; CAD Ṭ, 97.

1119 Kaufman 1974, 109 + n. 390; Stolper 1989, 299-303.

1120 Porten 1968, 55-58; Stolper 1989, 299-303; Dušek 2007, 509-510; Tavernier 2008, 70-73; Fried 2012, 45-46; Kuhrt 2014, 131-132.

1121 TAD A 6.2:23 (411 BCE).

1122 Bongenaar 1997, 451, 461; Jursa 2005a, 128-129 + n. 988. The document belongs to his archive (Jursa 2005a, 129).

1123 At some points, my readings of the text are divergent from Bloch's edition. See Jursa and Waerzeggers 2009, 255-257. Caroline Waerzeggers kindly provided me with her transliteration of the text.

1124 The document belongs to the Ilia D archive (Jursa 2005a, 87-88; Waerzeggers 2005, 355356 ; 2010a, 351 n. 1183, 434-435). On the different branches of the Ilia family and their social world, see Waerzeggers 2010a, 153-195, 372-437.
} 
a Judean sēpiru. ${ }^{1125}$ The sēpiru's name is broken off, but his father bore the Yahwistic name Zakar-Yāma. If the broken text is understood correctly, this Judean was a sēpiru of the troops or workmen (ummānu) and a subordinate of the rab kașiri, a high official in charge of the royal treasury. ${ }^{1126}$ This terminology is reminiscent of the hatru of the sēpirus of the troops (uqu) in the Murašû archive, but there is hardly a real connection between the Judean sêpiru in Babylon and the Judean farmers in the Nippur countryside. The seepirus of the troops were high-ranking officials in the Murašû archive, ${ }^{1127}$ but Judeans only cultivated land properties at their disposal. On the contrary, the anonymous son of ZakarYāma was a government official of some importance, as he collected taxes from prominent Babylonian families.

Officials of Judean and West Semitic background travelled from Babylonia to Susa for the purpose of taxation. Two promissory notes (OECT $10152=$ Bloch 2014 no. 7, 18-I-28 Dar, 494 BCE; and VS 6155 = Bloch 2014 no. 8, 6-VIII-29 Dar, 493 BCE) record the presence of prominent Babylonians in the Persian capital Susa. ${ }^{1128}$ These texts relate to the wider phenomenon discussed in Section 5.3.2: in an attempt to control Babylonia and its tax flows, Persian kings made people from the province regularly visit the Persian court at Susa. The Babylonian visitors included businessmen and officials, generally people responsible for taxation or tax payments in one way or the other. ${ }^{1129}$ The texts discussed here belong to the archives of two important families of the Babylonian urban elite, the Egibis of Babylon (OECT 10 152) and the Ilias of Borsippa (VS 6155). ${ }^{1130}$

The parties, witnesses, and scribes of the documents have traditional Babylonian names, the only exceptions being Yāhû-šar-ușur/Šamaš-iddin (OECT 10 152), Nabû-ahhē-šullim/Aqbi-il, and Šabbatāya/Nabû-šar-bulliṭ (VS 6 155). Yāhû-šar-uṣur bears a name with a Babylonian predicate and the Yahwistic

1125 Pasa'du ('equipment costs') and qaštu ('bow tax') are mentioned. See Jursa and Waerzeggers 2009, 255-257; Jursa 2011a, 441-442 + n. 62.

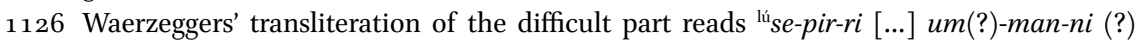
ina(?) šu ${ }^{\mathrm{II}} \mathrm{I} z a b$-[...] gal-ka-șir. See the comments and transliterations in Jursa 2010a, $249 \mathrm{n}$. 1474; Waerzeggers 2014b, $141+$ n. 68; Zadok 2014a, 116-117; Bloch 2018 no. 79. The word итmа̄nu is rare in Babylonian legal and administrative texts from the mid-first millennium; see CAD U-W, 102-108. On the rab kașirii, see Bongenaar 1997, 136-137; Stolper 2006a, 229; Jursa 2010b, 82-83.

1127 Section 5.3.2.

1128 On these texts, see Bloch 2014, 137-139, 161-167.

1129 Waerzeggers 2010b.

1130 Waerzeggers 2010b, 783. On the Egibi family and its archive, see Wunsch 1993, 1999, 2000a, 200ob, 2007; Abraham 2004; Jursa 2005a, 65-66. VS 6155 belongs to the Ilia D archive. On the Ilia family, see above in this chapter. 
theophoric element, the name Aqbi-il is West Semitic, ${ }^{1131}$ and Šabbatāya is a West Semitic name often possessed by Judeans. ${ }^{1132}$ Yāhû-šar-uṣur's name suggests that he was a Judean connected to the royal administration in Babylonia, in the same vein as Bēl-/Yāhû-šar-uṣur in Yāhūdu. ${ }^{1133}$ Šabbatāya's father Nabûšar-bullit also had a name that connects him to the royal administration, and his son's presence in Susa suggests that Šabbatāya continued in his father's footsteps. However, as Šabbatāya was not an exclusively Judean name, his Judean origin remains no more than a possibility. ${ }^{1134}$ Since the visits of Babylonian officials to Susa are a well-attested phenomenon and since Yāhû-šar-ușur's and Šabbatāya's fathers had Babylonian names, we may conclude that both men were Babylonian officials responsible for tax-related matters.

Finally, we may add a certain Malak-Yāma to the list of Judean officials in Babylonia. He appears as a messenger of a courtier (ša rēššarri) in an unpublished text from the reign of Neriglissar. ${ }^{1135}$

Like their Judean colleagues in the land-for-service sector, the officials discussed above were predominantly involved in the collection of taxes from Babylonia. None of these men were high officials with considerable power and resources at their disposal, but their positions were more important than those of the minor tax collectors in the countryside. It is noteworthy that four out of five documents were written in the reign of Darius I, but this seems to be a mere coincidence since several Judean royal officials are attested already in the Neo-Babylonian period. ${ }^{1136}$

\subsection{Temples}

Although many spheres of Babylonian society, including the administration, trade, crafts, and the military, were open to deportees, the temple cult was not. Rigid rules of access characterised Babylonian temples, and the sacrificial cult

1131 Zadok 1977, 32, 80; Pearce and Wunsch 2014, 40; but cf. Bloch 2014, 139.

1132 Coogan 1976a, 34-35, 84; Section 1.5.

$1133 \mathrm{C}_{2}-4$; see Section 4.4. On the Beamtennamen of royal officials, see Section 1.5. See the thorough discussion of Judeans with Beamtennamen in Bloch 2014, 135-141.

1134 Section 1.5; cf. Bloch 2014, 139.

1135 According to Zadok $(2002,28)$, the document in the New York Public Library (box 43, 4?) belongs to the archive of Tabnēa/Zērūtu/Dannēa from Marad. On this archive, see Jursa 2010a, $90+$ n. 479. A witness of the document is perhaps a Judean as well (Ha-na-na-a[ma?]). I could not access this tablet during the course of my research.

1136 See above in this chapter. 
was run by a relatively small number of Babylonian families in each city. ${ }^{1137}$ There was a strict hierarchy among these families as well, and only the socalled 'temple enterers' (érib bititi) were allowed to access the innermost parts of the temple. No Judeans or other deportees made their way into the closed priestly circles and participated in the temple cult. Nevertheless, temples were large institutions with multifaceted economic interests, ${ }^{1138}$ and dependent personnel, hired men, and contractors of local and foreign origin took care of their holdings. Although Babylonian kings donated deportees and other spoils of war to temples, ${ }^{1139}$ in many cases it remains unclear if a Judean person was hired by or dependent on the temple.

Three documents from the Ebabbar archive pertain to Judeans working for the temple of Šamaš in Sippar. ${ }^{1140}$ A woman named Yāhû-dimri and two sūtu (12 litres) of flour are mentioned in CT 57700 (1-II, no year). ${ }^{1141}$ The short receipt does not reveal anything else about Yāhû-dimri or the background of the transaction, but it seems quite probable that the recipient of the flour was Ebabbar and the woman belonged to the temple's dependent personnel. Moreover, two Judeans, Banā-Yāma and Natan-Yāma, are listed among 22 hired men of a certain Ile ${ }^{2}$ i-Marduk in CT ${ }_{5}^{6} 795$ (no date). Although Ile? $\mathrm{i}$-Marduk cannot be identified with any known person from the Ebabbar archive, he was most likely the foreman of the work gang in question. Finally, someone with a broken Yahwistic name (-ki-ia-a-ma) is attested in the badly preserved text CT 55 341 (several dates, no year). The text refers to sailors (malähu) and bitumen (kupru), and the Judean is to be counted among the sailors working for Ebabbar as well.

An intimate witness to the Judean presence in Sippar is a love affair documented in Cyr 307 (3-IV-8 Cyr, 531 BCE). ${ }^{1142}$ It is a judicial document ${ }^{1143}$ regulating

1137 Waerzeggers 2010a, 2011; Still 2019.

1138 Jursa 1995, 2010a, esp. 316-623; MacGinnis 1995; Bongenaar 1997; Da Riva 2002; Kleber 2008; Kozuh 2014.

1139 Section 8.2.

1140 These documents probably originate from the Ebabbar temple in Sippar, although their find-spots are unknown and the temple or city is not mentioned in the documents. The documents are receipts and lists typical of an institutional administration (Jursa 2004c, 2005a, 118-120), and they belong to the British Museum 82-7-14 collection, which is primarily comprised of material from Sippar (Reade 1986, xxxiii). See also Waerzeggers (forthcoming c).

1141 The copy in CT 57 has 'hu' as the last sign of the name, but the correct reading is 'ri', according to Zadok 2002, 35 .

1142 For a transliteration and translation, see Joannès 1994. The document is also discussed in Abraham 2005/2006, 211; Waerzeggers (forthcoming c).

1143 On the genre of the document, see Holtz 2009, 209-217. 
the relationship between a Judean girl called Țābat-Ǐšsar/Yaše-Yāma ${ }^{1144}$ and a man named Kulû/Kalbā. It appears that the two had been meeting each other outside the framework of an officially established marriage, which was not tolerated by their families or guardians. The document states that Țābat-Ǐšar should not meet Kulû anymore or that she should ask the head of her house (bēl bìti) to write to Kulû's father Kalbā. If she did not do this and was again found with Kulû, she would be marked as a slave. ${ }^{1145}$ Ṭābat-Iššar's mother Halâ was present at the writing of the document, but no other family members of Taabat-Iššar or Kulû appear to have been involved in the process. Instead of parents or brothers, the Ebabbar temple probably played a decisive role in regulating the behaviour of the two lovers. ${ }^{1146}$ First, this is suggested by the obscure reference to the bè l biti and by the fact that the issue was not solved within and between the families. Second, although it remains unclear which legal body delivered the verdict, a rent farmer (ša muhhi sūti ša Šamaš) of Ebabbar and a priest of the temple witnessed the document. ${ }^{1147}$ This raises the possibility that the girl and perhaps the man as well were somehow attached to the temple, either as dependants or free workers. ${ }^{1148}$

A number of texts from the Ebabbar archive pertain to Judeans who were involved in the agricultural sector of the temple's economy. A certain HūlYâma delivered dates to the temple, according to the administrative list CT 57 197, and he was most probably a gardener himself. ${ }^{1149}$ Nothing in the document suggests that he was more than a small farmer who cultivated a plot of temple land and had to deliver a share of his harvest to Ebabbar.

1144 The name Țābat-Iššar is Assyrian (Zadok 2002, 30-31). Zadok (1995, 3; 2014a, 111; 2015b, 175 $+n$. 80) notes the presence of Assyrian names in sixth-century Sippar and reasonably suggests that these people had migrated from Assyria and Upper Mesopotamia to Northern Babylonia. According to Zadok, Țābat-Iššar's family was of Judean or Israelite descent, having perhaps migrated from Upper Mesopotamia to Babylonia as well. However, it is also possible that the family had people of Assyrian origin among its acquaintances and this affected its naming practices.

1145 This may also be a figurative expression; see Wunsch and Magdalene 2014, 339 n. 19.

1146 Joannès 1994; Abraham 2005/2006, 211; Waerzeggers (forthcoming c).

1147 On the rent farmer Šāpik-zēri/Šamaš-ah-iddin, see Jursa 1995, 99; on rent farmers in general, see Jursa 1995, 85-116; van Driel 1999, 216-217. The second witness Šamaš-erība/ Balīhu/Šangû-Šamaš held a brewer's prebend at Ebabbar (see Bongenaar 1997, 225, 455456). The scribe of the document, Arad-Bēl/Bēl-ušallim/Adad-šamê, was a frequent scribe of judicial documents in Sippar (Bongenaar 1997, 66, 481-482), although he was a businessman without any apparent connections to the temple (Waerzeggers 2014a, 21-22, 89; cf. Bongenaar 2000, 85-88; Jursa 2005a, 120-121).

1148 For different perspectives on this matter, see Joannès 1994; Abraham 2005/2006, 211; Berlejung 2018, 1063-1065; Waerzeggers (forthcoming c).

1149 On this text, see Zadok 2002, 36; Waerzeggers (forthcoming c). 
A better-known Judean is Minu-eššu/Yāhû-râm, who farmed Ebabbar's fields in the area of Tīl-gubbi. ${ }^{150} \mathrm{He}$ was a sharecropper who leased five kurru (6.75 hectares) of uncultivated land from the temple in order to reclaim it (Jursa 1995 no. 47; Sippar, 4-?-5 Nbn, 551-550 BCE). Six years later he still cultivated Ebabbar's fields in Till-gubbi, this time paying his share (zittu) of 1;0.5 kurru of sesame to the temple (CT 56 132; 13-VII-11 Nbn, 545 BCE). ${ }^{1151} \mathrm{He}$ was hardly a member of the temple's personnel but a (semi-)independent farmer cultivating institutional land.

It is possible that Minu-eššu's son and father are also attested in the Ebabbar archive. A certain Nabû-šar-ușur/Minu-eššu is attested in the Ebabbar document CT 5574 (Sippar, 27-IX-1 Dar, 520 BCE). ${ }^{1152} \mathrm{He}$ and two other men had to deliver a small amount of sesame and silver to a tithe farmer of Ebabbar as a remainder of the temple tithe (ešru) from Āl-Hummāya. ${ }^{1153}$ The three men appear to be farmers of temple land, and, given the reasonable time gap between CT 56132 and CT 55 74, it is very well possible that Nabû-šar-ușur's father was identical with Minu-eššu/Yāhû-râm. It is noteworthy that Nabû-šar-ușur bore a Beamtenname with the šarru element, which indicates that the family had connections to the royal administration or that it strived to create some. ${ }^{1154}$

Minu-eššu's father is possibly attested in SCT 100, an undated list of payments of unknown geographical origin. ${ }^{1155}$ A certain Yāhû-râm delivered more than 12 kurru of barley and flour, including transport costs (gimru $)^{1156}$ and income (erbu). ${ }^{1157}$ The recipient of the agricultural products and payments is not mentioned, but the text type and terminology point towards an institutional context, most likely a temple. ${ }^{1158}$ Given the rarity of the names of Minu-eššu and Yāhû-râm, it is very well possible that all four texts pertain to members of one family who cultivated Ebabbar's fields in the Sippar countryside. ${ }^{1159}$ The profile of these people resembles that of Judean farmers in the environs of Yāhūdu and Nippur, as they were obviously not temple dependants but farmers

\footnotetext{
$115^{0}$ See Jursa 1995, 141, 177, 230-233; 2010a, 338-340; Zadok 2002, 28; Waerzeggers 2014b, 140.

$115^{1}$ The text is transliterated and translated in Jursa 1995, 177.

$115^{2}$ See Zadok 2004, 111-112.

1153 On tithes and tithe farmers, see Jursa 1998a, esp. 42, 91 on the text in question. Jursa suggests that the place name Āl-Hummāya refers to a village of Cilicians, but Zadok (2005, 78-79) does not accept this on linguistic grounds.

1154 See Section 1.5.

1155 See Zadok 2014a, 119 .

1156 On gimru, see CAD G, 77-78; van Driel 2002, 171-172; Weszeli in Jursa 2010a, 140-141.

1157 On erbu, see Jursa 1995, 153, 156-157; van Driel 2002, 284; Kleber in Jursa 2010a, 541-547. Notice that erbu and ešru are sometimes interchangeable terms (Jursa 1998a, 88-89).

$115^{8}$ Zadok 2014a, 119 suggests that the text may originate from Sippar.

1159 Zadok 2004, 111; 2014a, 119 .
} 
who tilled institutional lands in somewhat marginal rural areas. ${ }^{1160}$ Nabû-šarușur's name may indicate that instead of being dependent on the Ebabbar temple, the family was somehow attached to the royal administration, perhaps via the land-for-service scheme.

Furthermore, a document from the Ebabbar archive hints at the possibility that Israelites or Judeans were present in Babylonia already in the late seventh century. A certain Gir-re-e-ma and five other people with Akkadian names had a huge flock of sheep at their disposal in the Nippur region, according to CTMMA 41 (= BE 8 141). The document was written in the last years of Assyrian rule in Babylonia, in the accession year of Sîn-šum-līšir (626 BCE). ${ }^{1161}$ The total value of the animals was no less than 30 talents of silver, and the value of a single sheep is specified as being 1 shekel. Accordingly, the total number of sheep was 108,000 animals. Gir-re-e-ma and his companions were perhaps herdsmen contracted to care for Ebabbar's flocks because a purchase of this scale seems unlikely, especially during the turbulent political situation in Babylonia. ${ }^{1162}$ In any case, the importance of the transaction is emphasised by the fact that the qīpu of Ebabbar, Bēl-īpuš, was present in Nippur where the document was written. ${ }^{1163}$ If the spelling Gir-re-e-ma represents a Yahwistic name, this document is unique in two ways. ${ }^{1164}$ First, it pertains to a man of Judean or Israelite descent who was involved in the herding of a massive flock of thousands of sheep. Second, it would be the earliest occurrence of a Yahwistic name in Babylonian cuneiform sources, and it would predate Nebuchadnezzar II's deportations from Judah. This implies that if Gir-re-e-ma is indeed a Yahwistic name, its bearer was probably a descendant of Israelite or Judean deportees who arrived in Mesopotamia in the eighth century. ${ }^{165}$

Although every document discussed above originates from the archive of the Ebabbar temple in Sippar, there is no reason to assume that Judeans did not have contact with other Babylonian temples. A piece of evidence which supports this assumption is $\mathrm{BM} 103632$, an administrative list which belongs to

\footnotetext{
116o See Jursa 2010a, 339; Waerzeggers 2014b, 140.

1161 On Sîn-šum-lǐšir's reign and Ebabbar texts from this period, see Da Riva 2001.

1162 See Spar and Jursa 2014, 4.

1163 The qipu was a high official, royal representative in the administration of a Babylonian temple. He had no cultic duties, but he took care of the king's interests in the temple (Bongenaar 1997, 34-55; Waerzeggers 2010a, 42-43).

1164 Zadok (1979a, 34; 2002, 27; 2014a, 110) identifies Gir-re-e-ma as a Yahwistic name. However, the orthography of the Yahwistic element is peculiar, and the form -e-ma is attested only in one other document (C18; see Zadok 2002, 14; Pearce and Wunsch 2014, 23-24). Moreover, there are no other attestations of Yahwistic names in Babylonia before 597 .

1165 Zadok 2014a, 110.
} 
the British Museum 1911-4-8 collection. ${ }^{1166}$ The document lists sheep which were given to a certain Nìr-Yāma, to a household (bìtu), and to a certain Inašär-Bēl-abluț. Some of the sheep were given as travel provisions for journeys to Babylon and Kiš, but the list does not indicate the reason why Nīr-Yāma was among the recipients. The text type, references to a household, and distribution of travel provisions suggest that the document originates from an institutional context. A possible candidate is the Ebabbar temple in Larsa, as some documents from its archives have found their way into the 1911-4-8 collection, together with the Itti-Šamaš-balāțu archive. ${ }^{1167}$

The documents discussed above shed light on the different roles Judeans had vis-à-vis Babylonian temples, but their small number emphasises that only few Judean deportees were donated to the temples. Although the word širku ('temple dependant') ${ }^{1168}$ is never used to characterise a Judean, some of the people discussed above were most likely temple dependants. At the same time, Judeans also rented temple lands for cultivation on a seemingly voluntary basis and without any formal ties to the temple. Given the huge size of the temple archives from Sippar and Uruk, very few Judeans are attested in temple-related documents. ${ }^{1169}$ This is in stark contrast to the situation in the land-for-service sector, and it strongly indicates that the state primarily integrated deportees into its own economic sphere. Temples played only a minor role in Babylonian deportation schemes.

\subsection{Royal Lands and the Land-for-Service Sector}

Throughout this study, Judeans have primarily been attested in contexts which relate to the royal administration and land-for-service sector in one way or another. A number of miscellaneous texts can be added to this group.

A Judean man called Yāhû-nūru/Zabdia cultivated land in Bīt-Nabû-lềi in the Borsippa countryside, according to VS 36 (Bìt-Nabû-lê'i, 2o-VII-22 Nbk, 583 ВСE). ${ }^{1170}$ He owed a debt of $1 ; 3$ kurru of barley to a certain Mušẽzib-Bēl//Tunāya,

1166 The tablet is unpublished, but its transliteration is available at CTIJ. My remarks are based on this transliteration and the information available in Jursa 2010a, 133-134 n. 804; Zadok 2014a, 121.

1167 Jursa 2005a, 108-109; 2010a, 133-134 n. 804; but cf. Zadok 2014a, 121.

1168 On širkus, see Kleber 2011.

1169 The Ebabbar and Eanna archives comprise tens of thousands of documents in total (Jursa 2005a, 116-120, 138-139).

1170 See Zadok 2004, 108-109; Waerzeggers 2014b, 136. The reading of the first sign of Yāhûnūru's name is uncertain (Ia?-a-hu-nu-ú-ri), and there is thus a slight chance that the name is not Yahwistic. 
who managed farmlands in the service of Marduk-šāpik-zēri//Eppēešilī and Ṭābia//Sîn-ilī.1171 The debt bore no interest, outstanding debts or tax payments are not referred to, and the debt was to be paid back at the time of the next barley harvest. Accordingly, the promissory note most probably disguises the prepaid purchase of a future harvest. ${ }^{1172}$ As it is known that Ṭābia and MušēzibBēl leased and organised the cultivation of royal lands, ${ }^{1173}$ Yāhû-nūru was not necessarily an independent farmer but an agricultural worker in Mušēzib-Bēl's service or a farmer in the land-for-service sector. ${ }^{1174}$

YOS 1936 is a promissory note for 5;2.3 kurru of barley given as capital to a harrānu venture (Nippur, 13-I-14 Nbn, 542 BCE). ${ }^{1175}$ The document belongs to the archive of Bēl-ețēri-Šamaš/Aplā, an entrepreneur who was - among other things - involved in the management of royal lands in the Nippur region. ${ }^{1176}$ yos $193^{6}$ pertains to a harrānu venture in which Bēl-ețēri-Šamaš and another man participated as active partners and which was financed by a certain Bēlețēri-Šamaš/Zarīqu-ēreš. The latter had lent over 65 kurru of barley from royal property to Bēl-ețēri-Šamaš/Aplā already four years earlier (Yos 19 34). It is thus likely that the harrānu venture in Yos 1936 had royal backing as well, either as a direct royal investment or as a private investment of harvest cultivated on royal land. ${ }^{1177}$ A Judean named Kutāya/Ahu-Yāma was among the witnesses of the document. ${ }^{1178}$ If he was not randomly chosen to witness the deed, it is possible that he was involved in farming or managing royal properties in the Nippur countryside.

Two roughly contemporary documents from well-known private archives further strengthen the view that the great majority of Judeans were indeed settled on royal land or were otherwise connected to the royal administration in Babylonia. Documents from the archives of the Egibis ${ }^{1179}$ and

\footnotetext{
1171 The document belongs to the Sîn-ilī archive. See Wunsch 1988; Jursa 2005a, 69-71; 2010a, $210-211$.

1172 See Jursa 2010a, 211-212.

1173 Jursa 2010a, 210; Waerzeggers 2014b, 136.

1174 Cf. Jursa 2010a, 210.

1175 The text is re-edited and translated as no. 10 in Jursa 2005b.

1176 On the archive and business profile of Bēl-ețēri-Šamaš, see Jursa 2005a, 112; 2005b.

1177 See Jursa 2005b, 209.

1178 His name Kutāya ('Cuthean') is an interesting example of Judean name-giving practices in Babylonia. On the name, see Zadok 2002, 28; Vanderhooft 2017, 122. On the city of Cutha, see Jursa 2010a, 115-116, 124-126.

1179 See Section 6.1.
} 
Marduk-rēmanni ${ }^{1180}$ relate to various spheres of Babylonian society, but the few Judeans attested in the archives appear in contexts connected to the royal administration. In addition to the cases discussed above, ${ }^{1181}$ these archives refer to two Judeans named Nīr-Yāma/Bēl-zēr-ibni and Haddāya/Yāhû-qâm. Both Judeans appear in dossiers which relate to the private management of institutional land. Nīr-Yāma guaranteed a substantial payment of 16 minas of silver on behalf of two men working for Marduk-nāșir-apli//Egibi in Dar 310 (Babylon, 9-XI-11 Dar, 510 BCE). ${ }^{1182}$ The debt originated from Marduk-nāṣirapli's purchases of commodities produced on institutional - temple and royal - land in Šahrinnu in the environs of Babylon. ${ }^{1183}$ Given the large amount of silver involved, Nīr-Yāma was hardly a small farmer but perhaps one of Marduknāṣir-apli's local associates in Šahrīnu. On the contrary, Haddāya/Yāhû-qâm was hardly more than a farmer of royal land in the village of Zazannu in the Sippar countryside (MR 9o; Zazannu Ālu-ša-Bēl-iddin, 14 Dar, 508-507 BCE). ${ }^{1184}$ Marduk-rēmanni//Șāhit-ginê leased royal lands from a high official in Zazannu and organised their cultivation through subleases. ${ }^{1185} \mathrm{MR} 90$ is a receipt relating to these subleases, and it was written at the estate of the high official in charge of the leased lands. Haddāya appears among the witnesses, and his status is probably equal to those small farmers who witnessed documents in other regional centres, such as Našar.

Three Judeans are attested in a sale of oxen belonging to the Tattannu archive. ${ }^{1186}$ At least one of them was a servant of Tattannu II, a member of the rich, archive-holding family. The businesses of the family pertained to tax farming and to the management of royal properties in the land-for-service sector, and, moreover, the eldest protagonist of the archive, Tattannu I, was perhaps identical with the homonymous governor of Across-the-River. ${ }^{1187}$

1180 Also known as the Șāhit-ginê A archive. See Jursa 2005a, 125-126; Waerzeggers 2014a; Section 3.3.2.

1181 The royal official Yāhû-šar-ușur/Šamaš-iddin (OECT 10 152; see Section 6.1) and the merchant Aia-ahâ/Šani-Yāma ( $N b k$ 361; see Section 3.4) are attested in the Egibi archive. Aia-ahâ's connection to the royal administration is suggested by his participation in longdistance trade.

1182 The text is transliterated and translated in Abraham 2004 no. 106.

1183 Abraham 2004, 118-127. On the location of Šahrīnu, see Zadok 1985, 283-284.

1184 On the location of Zazannu, see Zadok 1985, 334; Waerzeggers 2014a, 157 + n. 26.

1185 Waerzeggers 2014a, 157-159.

1186 HSM 1931.1.1 (the village of $\mathrm{Hu}$-ia, 2-III-11+ Art I, 454-445 BCE). The document is unpublished but transliterated at CTIJ. The text features Gabrī-Yāma/Bēl-ittannu (if the reading of the broken name is correct) and his father and brother. See Zadok 2014a, 120-121.

1187 Jursa and Stolper 2007; Jursa 2010a, 375. On the Tattannu archive, see Jursa 2005a, 94-97. 
Although the sale of oxen does not pertain to royal concerns, the Judeans served a family with obvious connections to the royal administration.

Finally, three more documents can be added to the cases discussed above. First, a Judean named $\mathrm{d} I a-(a)-h u-u-m u-[. .$.$] witnessed two documents relating$ to the rent farming of royal lands in the environs of Isin. ${ }^{1188}$ Second, TCL 13210 is a list of debts and remaining payments in barley owed by a number of people, some of whom bore Arabian names. ${ }^{1189}$ A Judean man called Malak-Yāma was in charge of the respective promissory notes and held them at the estate (bït) of someone called Kabar-il. ${ }^{1190}$ The Judean and Arabian personal names and a reference to a rural estate are indicative of an environment typical of the land-for-service sector.

The texts analysed in this section are additional evidence of Judeans who were integrated into the sphere of the royal administration or royal landholdings in one way or another. The texts emphasise that the environs of Yāhūdu and the Nippur countryside were not special cases, as the king and his officials also held land properties in other parts of Babylonia. Deportees were resettled in these rural areas as well.

\subsection{Miscellaneous Texts}

There are a small number of documents which cannot be properly contextualised and which thus yield only little information on Judeans. These include a broken document witnessed by $I-u-h u-{ }^{2} /$ Zababa-iddin in Kišs(Hursagkalamma), ${ }^{1191}$ a receipt of a rental payment concerning a house owned by ${ }^{\mathrm{Id}} I a^{-}{ }^{2}-u^{\prime}-[\ldots]$ in Babylon, ${ }^{1192}$ a promissory note for a small amount of wheat and barley guaranteed

1188 ROMCT 225 and Stigers 1976 no. 44. Judging by the similar contents of the documents and the number of witnesses in common, they were probable drafted around the same time in Isin (14 Dar, 508-507 BCE). See Joannès 1986, 80. The tablets belong to the archive of Silim-Bēl/Arrabi, a rent farmer in Isin (Joannès 1986, 80; van Driel 1989, 214-215; Jursa 2005a, 102).

1189 The place and date of writing the document are not recorded. On the Arabian names, see Zadok 1981, 79 .

1190 Zadok's suggestion $(2002,45)$ that the broken personal name Ga-mir-[...] on line 10 should be emended as $G a-m i r-i[a-a-m a]$ is hypothetical.

1191 OЕСT 10183 (Hursagkalamma, 11-XI-17 Xer, $468 \mathrm{BCE}$ ). The broken document is perhaps related to agriculture. I am not certain if the name is Yahwistic (cf. Zadok 2002, 14), because the orthography has no parallels and the tablet in question cannot be linked to other documents mentioning Judeans.

1192 Cyr 43 (Babylon, 19-IV-2 Cyr, 537 BCE). The text is transliterated at Achemenet (http:// www.achemenet.com). 
by Zakar-Yāma/Sepā-Yāma in Nippur, ${ }^{1193}$ a sale of two female slaves by BanāYāma in Nippur, ${ }^{1194}$ and a sale of slaves witnessed by two Judeans in Cutha. ${ }^{1195}$

\subsection{Seals of Exiles}

A number of seals featuring Yahwistic and other supposedly Judean or Israelite names have been used as a further witness to the presence of Judeans and Israelites in Mesopotamia. ${ }^{196}$ However, as these seals are of unprovenanced origin, ${ }^{1197}$ any information about their archaeological context is permanently lost. ${ }^{1198}$ If they are indeed ancient artefacts, there is no way of knowing if they were manufactured in Mesopotamia or in the Levant in an Assyrian or Babylonian style. It has to be noted that no seals owned by Judeans have been found during controlled excavations in Babylonia. Although some cuneiform tablets from the environs of Yāhūdu and the Murašû archive bear seal impressions which attest to Judean seal ownership in Babylonia, none of these impressions include Hebrew or Aramaic writing. ${ }^{1199}$ This raises doubts about the Babylonian origin of the 'seals of exiles' and their alphabetic epigraphs, and, all in all, there remains the possibility that some of them are modern forgeries. Given the problematic circumstances, the seals will not be treated in this study.

\subsection{Conclusion}

The documents which pertain to Judeans but originate from several different Babylonian archives are instrumental in evaluating the picture which emerges

1193 TuM 2-3 123 (the eighth year of Artaxerxes II or III, the fourth century BCE). Because four people sealed the tablet, it was hardly written in the eighth year of Artaxerxes I (Zadok 2002, 45). The place of writing is broken, but the commodities were to be delivered in Nippur. Zakar-Yāma's ring is impressed on the tablet.

1194 N 4518, an unpublished, broken tablet at the University of Pennsylvania Museum of Archaeology and Anthropology (Nippur, 22-XII-? Dar, 521-486 вСЕ). The text is transliterated at CTIJ. See Zadok 2014a, 120.

1195 Unpublished BM 55063+55268 (25-XI-Art I, 464-424 BCE). See Zadok 2002, 40-41; Jursa 2003, 62. Collated in June 2014. I wish to thank the Trustees of the British Museum for their kind permission to study and cite from tablets in their care.

1196 Avigad 1965; Heltzer 2005.

1197 Heltzer 2005, 173 .

1198 On the ethical problems involved, see Section 1.4.2. On unprovenanced seals in particular, see Joffe 2003 .

1199 See Sections 4.3.6.3 and 5.7. 
from the preceding chapters of this study. These documents corroborate the view that Judeans were predominantly resettled in the land-for-service sector and that, in general, the state integrated deportees into its economic sphere. Relatively few Judeans were dependants of Babylonian temples or participated in farming of temple lands. It is noteworthy that documents from private archives also support this view: although the archive-holding Babylonian families had multi-faceted interests, Judeans are attested in contexts which relate to the royal administration or the cultivation of royal land. 